\title{
Facilitating a Dialogue
}

We at Projections have stated our purpose as being to 'facilitate a dialogue between people in the humanities and the sciences' (not a modest goal for a little journal first making its way in the world). We have intended to do this through what seems to us the medium that best synthesises art and technology and opens itself up to scientific investigation because of its complex perceptual nature-film. Our focus, at the same time, has been on the mind/ brain, since that seems to us the place were science and film best meet.

It is difficult to think of any living writers or social critics that could have such an impact on our zeitgeist today as Camus, Sartre, Hemingway, Marcuse and Levi-Straus had on the zeitgeist after the Second World War. We now live in an age when science and technology most directly influence our thinking and are writing the pages of our intellectual history: when science is reshaping our vision of self and society. In our digital age our notions of space and reality have been irrevocably altered. The concepts of genetics, neuroscience and evolution have had more of an impact on our self-image than the ideas of any living writers or thinkers.

In this third issue we bring science and art more closely together than we have in the first two issues. Uri Hasson and his colleagues introduce us to the field of 'neurocinematics,' in which the readings of an fMRI brain scanner open up a window for us to view the workings of the brain in the process of watching a film. More than demonstrating the mechanics of visual and auditory perception, this essay gives us some preliminary ways of understanding aesthetics scientifically, and offers filmmakers an extraordinary opportunity to understand and shape their craft.

We follow Hasson's essay about neuroscience and film with Lissa Weinstein and Banu Seckin's subtly psychoanalytic reading of the metaphysical comedy, Being John Malkovich. We do so because with all our desire for the scientific evidence of the laboratory, there is still a truth that comes from our common sense observation and understanding of human nature. What impresses about this essay is its avoidance of psychoanalytic jargon while still grounding itself in psychoanalytic principle based upon years of clinical observation-a genuine accomplishment with the film's complexity and humour. 
Your editors have been keeping their eyes and ears open, searching out conferences that might be of interest to our readers and hoping to find in them papers that might be developed into essays for our pages. One such conference of special quality and relevance took place at the University of Hamburg in December, 2005, 'Audiovisuelle Emotionen: Emotionsdarstellung und Emotionsvermittlung durch audiovisuelle Medienangebote' (Audiovisual Emotions: Representing and Eliciting Emotions through Audiovisual Media). The German edition of this conference's papers was published by Herbert von Halem Verlag (Köln) in 2007. We have been fortunate to be granted permission to publish English versions of what we consider the most relevant essays to our journal.

For this issue we present to our readers three essays on the subject of emotions in film. All three essays, like the others in the German volume, either implicitly or explicitly confront the age-old separation of emotion and cognition, seeking to bring the two together through such schools of thought as appraisal theory. What all three writers seem to do is apply a cognitive method of film analysis to the complex workings of emotion in both character and audience. Anne Bartsch makes a very subtle argument about how emotions evoke meta-emotions-emotions about emotions-that complicate, but also clarify for us the characters' responses and behaviour throughout the film. Murray Smith analyses emotional expression in film as a 'biocultural' phenomenon, both universal and culturally bound. He is especially engaging in explaining the accessibility of films to audiences from diverse cultures. And Lalita Pandit uses an entirely cultural perspective, 'Indic paradigms of devotional love and śänta rasa' ('the aesthetic emotion of peaceful pleasure') to explain the central characters' achievement of transcendence at the conclusion of three classic Indian films.

Once again we ask our readers to take note of the book reviews at the end of our journal that extend many of these essay's ideas and much of their discourse. Vivian Sobchack's review of Laura Mulvey's new book, Death $24 X$ a Second: Stillness and the Moving Image, is a sensitive and lucid account of Mulvey's reflections on cinema from the vantage point of the new digital technology. Paisley Livingston's review of Birgitta Steene's Ingmar Bergman: A Reference Guide becomes a lesson in historical methodology, and Bernard Roth's review of Andrew Gordon's Empire of Dreams: The Science Fiction and Fantasy Films of Steven Spielberg, gives us an interesting take on how a psychoanalyst views the work of a psychoanalytic film critic.

We welcome responses to all of these essays and book reviews for inclusion in our journal and, of course, responses to the responses. We also take pride in announcing that the film scholar and writer, Carl Plantinga has agreed to join Projections as an associate editor. 